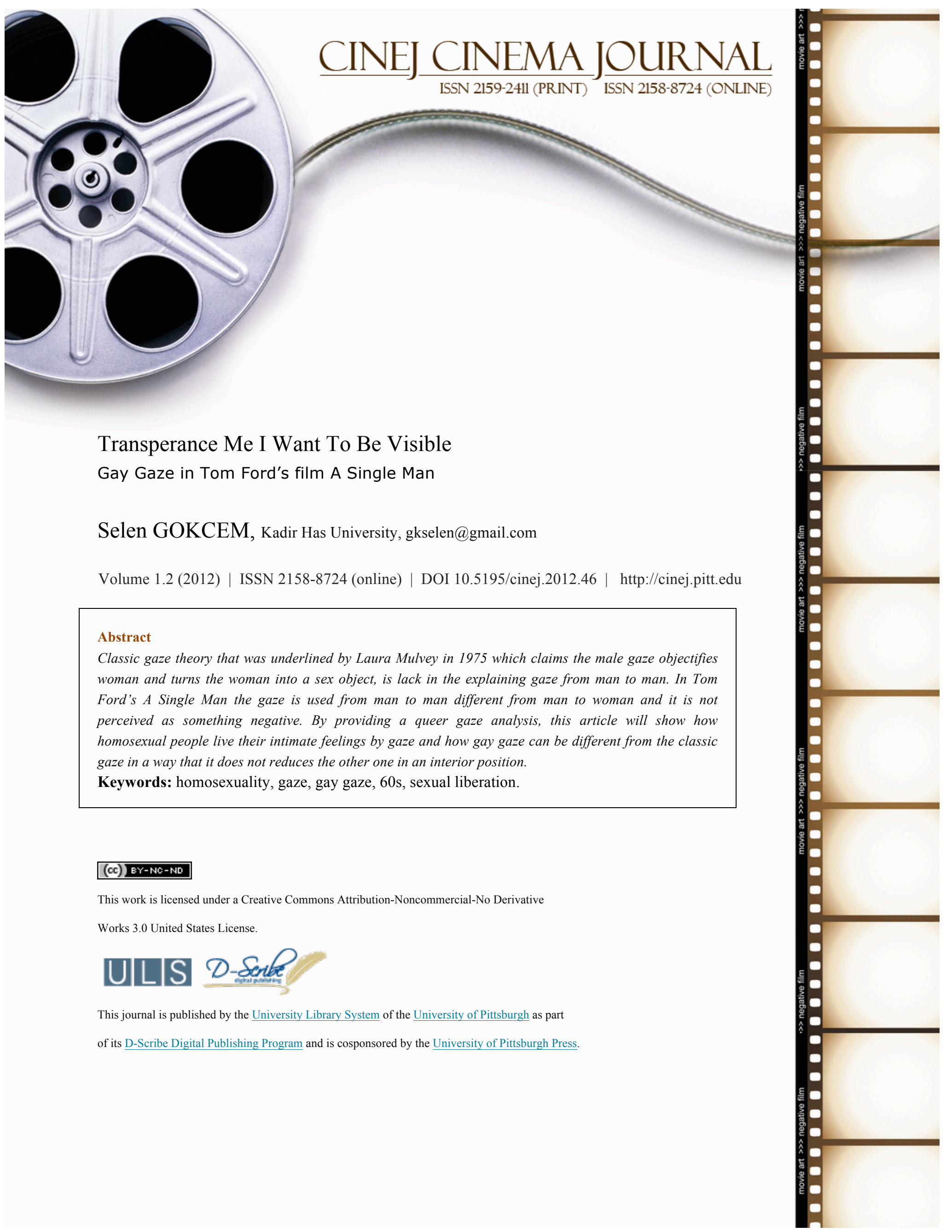




\section{Transperance Me I Want To Be Visible Gay Gaze in Tom Ford's film A Single Man}

A Single Man that is based on the novel of Christopher Isherwood's is a film by Tom Ford. It is a story about a university professor seeking for the meaning of life after his sixteen-year- long boyfriend died in a car accident. As a subject having a gay relationship in the 60s of Los Angeles, the film examines the secrets of lives under the light of a gay relationship by giving details of the era, changing lives and perception about nonstraightness in every notion of course of existence.

Being different in the story and the editing, the film focuses on a relationship that had been lived for sixteen years and had to be stopped living -physically- because of a car accident. It is the main part of the film that the university professor who is not able to resist living alone searching for the ways of living without his boyfriend. Even though this is a queer story, it is important to point out that, the film focuses on only one day after eight months Jim (Matthew Goode) died and the details and clues about the relationship are given with flashbacks. Thus, actually, during the film there is not an active gay relationship but just the memories of it. The agony of the George (Colin Firth) and his decision about 'this day is going to be different' from the others are followed with the help of clocks on the wall of his own home, of his car, of university and the class, and lastly of his bed side clock in order to indicate that is the last day of George without Jim. While analyzing this film A Single Man, I will question a queer relationship that was lived in $60 \mathrm{~s}$ when a number of freedom thought movements occurred in the sense of gaze by pointing out the gay gaze, the function and difference of it from a classical narrative male gaze towards female.

To start with, I would like to point out the era the 60 s in the United States that the film occurred. Even though the film was shot in 2010, it is meaningful to place a gay story in 1962 when a great number of changes came into existence especially in gender situation. However, it does not mean that the homosexuality was that easy to be accepted in the society. As Patricia Juliana Smith (The Queer Sixties, xii) explains 'Perhaps there were numerous ideas of sixties, according to the particular moment in time or the viewpoint of the individual preceptor. Nonetheless, even when such diversity is considered in academic discourse, it is clear that one group-queers or homosexuals as they were then called- surely does not own the sixties, for it is usually assumed, if we are to believe what we are told and read, that the decade's sexual liberation was heterosexual liberation'. Although, the sexual relationships among young university students, and the women who realized the freedom of sexual intercourse without getting married were accepted, the homosexuality was not openly lived in the society, but at homes invisible homosexuals' sacred place. The women's movements' symbols are the young university student Lois who is the only one smoke in the classroom and has sex with his friend and Charlotte (Julianne Moore) George's best friend who is divorced and lives alone, drinks alcohol and smokes, at the same time has a past that shared free sex with George as an experience. Besides, using drugs which is one of the most characteristic of $60 \mathrm{~s}$ is taken account and a professor and his student can talk about it and at the same time they can offer it to each other. However, the homosexuality was not liberal all the way at that time, the seeds of homosexual movements planted in the zeitgeist of the $60 \mathrm{~s}$, though.

The era of the film is important because although there was not open homosexuality, people were able to live gay relationships as life styles were open to changes at that time. Here, I think, it is better to explain what is queer or gay, and how being queer is analyzed. Alexander Doty points out in The Oxford Guide to Film Studies that (1998: 148) some use 'queer' as a hipper synonym for 'gay male', or less frequently, 'lesbian', or as a new umbrella term for gay and lesbian (and bisexual sometimes). As Richard Dyer suggests in the Culture of Queers (2002: 19) being queer is also being homosexual, but also being different'. He continues that, 'the gay movement was founded on the notion that homosexual is an identity; its assertion of the rights and worth of people who 
practiced same sex, sex was based on the idea that we were a kind of commodity of persons'. The film gives the gay couple as educated people like George is a professor at university and Jim is an architect. This is important because, not like any other gay relationships, in this film, George and Jim have been together sixteen years sharing the same home which explains the gayness they choose is conscious. In opposition to the general impression on homosexuality that was once listed as mental disorder, there is a scene that George and Jim are reading books, with the impression they always do, George reads Metamorphosis and Jim reads Breakfast at Tiffany. In the book of Plato, Shakespeare, Walt Whitman and Me by Chauncey, Duberman and Vicinus (1989:3), they give example how to be gay is hard as they need to prove themselves even though they are heroes, ' It has long been reassuring for gay people, raised in a society offering them no positive images of themselves, to claim gay heroes, ranging from Sappho, Julius Caesar and Shakespeare to Willa Cather, Walt Whitman and Gertrude Stein, and much of the earliest work by historians simply sought to establish in a more scholarly fashion the homosexuality attributed to certain respected historical figures'.

Living in a home surrounded by glasses is a kind of being transparency that can be referring two things; one is he claims to show there is nothing to hide in his life because he is 'normal' as much as other people, or he does not want to hide anything as being gay is his life style, his identity. In one of the scene shown by flashback, Jim wants to kiss George in the lips but George says he should learn how to live in a house surrounded by glasses, Jim answers 'we are invisible George, you said this, don't you remember'. Invisibility and transparency are two terms that can be identified with being queer in some aspects. Generally speaking, for most surveys that have been questioned about gay and lesbian representation, it has been imagined that queer people are invisible. However, on the contrary, later on, it has been suggested that homosexuality is not invisible, 'it's meanings and politics are perfectly obvious to us'. In this sense, it can be taken as being invisible here is that while the homosexuals are living in the way they want, even though the people around them feel something about their way of life, they do not dare to judge them as they do not know how to do. On the other hand, it can be suggested that, as the society has not accepted this non-straightness, they prefer not to see queers because minorities mean being unsystematic, and it gives birth to fear. In the film, in the classroom section while Professor George is giving example from the minority groups, he indicates that 'if those minorities are somehow invisible, the fear is much great. The fear is why the minority is persecuted. The cause is fear. Minorities are just people. People like us'. This sentence is a kind of explanation of what is queer to the society and why it causes fear. While George is giving these sentences as examples, he gives hints to the people like him and the invisible couple in the classroom who are afraid of being visible. Even though, today being queer is a situation that is much more visible, for the days in $60 \mathrm{~s}$ and earlier, it was not that easy to be visible as people were afraid of being not to go along with the crowd. Even for the George who has a gay relationship for sixteen years, was not easy to decide he was a gay or not. In another flashback given in black and white, where George and Jim lie in an place that is totally isolated and out of the city, they talk about the George's relationship with Charlotte that Jim thinks they seem really intimate to each other. George explains the situations and he says that once Charlotte and he slept and they tried to be a couple. And George adds that, normally every man has a relationship with a woman, or at least he sleeps with a woman in his entire life. However, Jim has not slept with a woman as he has not been interested any of them. This scene is a good example to prove that as being older than Jim, George felt necessity to sleep with a woman as it was the rule as a young boy. On the other hand, as being younger Jim was much surer about his gay feelings that he even did not try to sleep with a woman to prove himself that he did not like it. It shows that, even it was not so open, the more time changes, the more people become sure about their queer feelings with the help of free thoughts.

In the account of the queer relationships somehow are to be lived secretly, the eyes and the gaze undertake all the meanings. According to Higgins (1993, 235-6), Gay men are able to subtly communicate their 
shared worldview by a special gaze that seems to be unique to them... Most gay men develop a canny ability to instantly discern from the returned look or another man whether or not he is gay. The gay gaze is not only lingering, but also a visual probing...Almost everyone I interviewed said that they could tell who was gay by the presence or absence of this look. Gaze is a term that started to be on agenda after Mulvey's essay Visual Pleasure and Narrative Cinema in 1975 that is related with male look to the woman what makes woman fetish object. Moreover, she got help from psychoanalysis and used the term scopophilia which is Freud's term means 'pleasure in looking at another person as object' (Mulvey 1975: 839). However, 'Mulvey's model of gaze has been accused of remaining caught up in, and reproducing, phallocentric, heterocentric, and/or Eurocentric logic' (Sullivan, 198). As time passes, there has been much more queer film that, the gaze subject needed to be asked again for the other versions of genders. Mulvey, with her essay opened a new way in film with gaze by questioning or underlying the positions of gaze that are 'traditionally, the woman displayed has functioned on two levels: as erotic object for the characters within the screen story, and as erotic object for the spectator within the auditorium with a shifting tension between the looks on either side of the screen' (1975: 841-2). However, as this explanation was for heterosexual gaze from man to woman, this essay was not enough to explain queer gazes in film that from man to man or from woman to woman. According to Drukman, "for the gay male spectator, the object of scopophilic pleasure is the man (whilst in Mulvey's schema it is the woman) and the subject of ego-identification is ...in constant flux between the woman and the man' (1995: 84-5). Here, it can be suggested that by explaining the gaze in this way, Drukman means the male is subjected to gaze of male spectator and he becomes objectified in this sense, feminized as it was called 'transitivism' that underlined in Mulvey's essay in 1981. From another perspective, looking codes mean a lot in gender subject that differentiate woman from man. As Dyer gives an example, 'men could look freely at women, but women could only glance back surreptitiously' (1992: 103). In the public places or in the society men have a right to look to whom he wants to. If I go back to A Single Man, there are a great number of looking and gazing in the sense of queer. As gayness is not open in the society in the film, the very used organs are eyes that are at the same time the carriers of meanings and the moments of feelings. The first eyes that are seen in the film are Jim's lifeless eyes now represent the connection came to an end as he died. After the very first eye scene, throughout the film, George has eye contact with people who can communicate with their eyes. Especially one of George's students Kenny who has queer feelings and remind Jim to George, talks with his eyes. Even though the eyes are important, their function is important either in the sense of their direction. A Single Man frees the naked body of men and at the same time objectifies it with the gazes of George in the film and with male spectators out of the film. From the very first moments of the film until the end of it, naked male bodies are seen and with slow motions and close ups, they are shown by the directors with a pleasure. As an example, at school while George is talking to a friend, a few half naked men who are playing tennis calls his attention and with a pleasure he watches men's bodies. At the same time with the help of close ups, the bodies become more attractive. Thus, it is possible to say that, not only woman but also male body can be attractive for queer people. Drukman suggest that 'the gay man can be both maker of meaning and bearer of the look'. In the scene where George meets a young and very attractive Spanish man and talks to him with a great pleasure by doing compliments, the eyes and after the lips are the main attraction points given from the eyes of George in order to prove that a man can be attractive for another man, it just changes who looks to whom with what feelings. Another scene where naked body and gaze are used together is the one that Kenny and George are swimming all naked at night and also this is when Kenny says 'we are invisible, aren't we' that explains Kenny's secret feelings about being queer. Later on, at George's home, when Kenny gets undress in the very front of George after seeing Jim's naked photograph in the drawer, George looks at directly to the naked body of Kenny with a pleasure that proves the way of look is important, and even though different from the classical gaze, it shows that the queers both gay and lesbians can see things from a different way as everyone,-straight people- see. According to John M. Clum, 'the naked male body, figures the power of what- sexual chaos, mystery, the unknown and homosexuality'. 
And he continues, 'the sight of the nude man as a scapular object, the viewing of the male nude as a pleasure activity, is a common element of gay theater'. Thus, in this sense, it is blatant that, the queer desire is represented here by the gay gaze is important in the sense of film that leads spectators views wherever or whoever it wants. Different from the classic narrative gaze theory only from man to woman who objectifies woman, 'the nude man here is placing himself in the passive position of object of the gaze, as men are supposed to be lookers, not the objects of the gaze'

Last but not least, to make better impression and to prove what he wants to show, Ford uses noteworthy filmic techniques in A Single Man. As the story is not being lived during the film but lived eight months ago, the flashbacks tell the queer story which helps to make the film nostalgic and an unforgettable love story between two men. Slow motions help to feel the agony of George when he remembers Jim and at the same time happiness and pleasure when he looks in the eyes of meaningful people. Especially, the slow motions, when he looks into the eye of Kenny and the Spanish young man, unites the pale and dull color of George's miserable life and vivid colors of happiness and good feelings. By using the color shift, the director allows the colors make difference between the feelings and time, between the ordinary and special and between the very moment and past. The exterior voice of George who tells the story a little bit is united with first point of view and turns the story into a real man's story. Besides, the heavy rain's sound in the scene where George learns Jim is death and runs into the house of Charlotte, is the only sound that is used as background music while the editing includes jump cuts which enables to give George's misery and fragmented self. The clock detail which shows the real time from the moment George wakes up by dreaming Jim' accident scene to the his last moments enables the viewer to see a man's last day or last hours to be lived. Related with the gaze, the eye details and the gazes from George to the men he feels intimacy are focused with close ups and vivid colors or lightening to support the good feelings that George has in the sense of queer feelings as in the meaning man who reminds Jim makes him happy. Slow motions, dreamy like scenes, different color flashbacks and combinations of past memory and now are the very noteworthy techniques that help the film become remarkable.

As a conclusion, it can be asserted that, as a story telling a sixteen-year-old queer relationship between two men, A Single Man is a notable film that uses the gaze from man to man in a brilliant way. Different from the classical gaze theory that was underlined by Mulvey in 1975, which claims the male gaze objectifies woman and turns the woman into a sex object, here in this film there is a gaze from man to man that shifts from one to the other, and it is not perceived something negative. Thus, even though in the gay gaze there is also an objectified one, as it is in the same sex it just represent the gaze which reflects the secret feelings to the other man, but not reduces the other one in an interior position. As the gaze is mutual, as the gaze is the way to point out the gayness, it is welcomed. While a conscious gay relationship is the center of the film and one of the most important messages is the gays are not mentally disordered or uneducated, how it can be a real relationship between a university professor and an architect, and how it can be deeply sad to lose its partner as a gay are emphasized during the film. Under the pressure of wars and the changing minds of $60 \mathrm{~s}$, how a gay relationship can be lived with the help of gaze- that represent the very relationship in queer sometimes- is told with noteworthy techniques to give the feelings much more effective. As a last word, if there is a term that queer gaze it is not only related with lesbians, gays or queers, but that is related to everyone who has queer lives, queer looks, or 'queer moments' sometimes. 


\section{References}

Clum, M. John. (1992). Still Acting Gay: Male Homosexuality in Modern Drama. Columbia University Press.

Dyer, R. (2002). The Culture of Queers. Routledge, London.

Heale, J.M. (2001). The Sixties in America, History, Politics and Protest. Edinburgh University Press.

Hill, J. Gibson, C. (1998). The Oxford Guide to Film Studies. Oxford University Press.

Patrick, H. (1993). A Queer Reader. New Press.

Quinn E., Dolan J. P. (1968). The Sense of the 60s. New York the Free Press.

Smith, P. Juliana. (1999). The Queer Sixties. Routledge. London. 